\title{
DEGRADATION KINETICS OF ORGANIC MATTER IN DAIRY INDUSTRY WASTEWATER BY FLOTATION/OZONATION PROCESSES
}

\author{
CINÉTICA DE DEGRADAÇÃO DA MATÉRIA ORGÂNICA NAS ÁGUAS \\ RESIDUÁRIAS DA INDÚSTRIA DE LATICÍNIOS PELOS PROCESSOS DE \\ FLOTAÇÃO/OZONIZAÇÃO
}

\author{
Marta Cristina Silva CARVALHO ${ }^{1,2}$; Alisson Carraro BORGES ${ }^{2^{*}}$; \\ Magno dos Santos PEREIRA ${ }^{2}$; Fernanda Fernandes HELENO ${ }^{2}$; \\ Lêda Rita D'Antonino FARONI ${ }^{2}$; Luiza Cintra CAMPOS ${ }^{3}$ \\ 1. Instituto Federal Baiano, Catu, BA, Brasil; 2. Universidade Federal de Viçosa, Viçosa, MG, Brasil, borges@ufv.br; \\ 3. University College London, Londres, Reino Unido.
}

\begin{abstract}
This study evaluated the adjustment of four kinetic models and their respective parameters on data of dairy wastewater treatment by the physico-chemical process of flotation and ozonation. The experiment was implemented during the year 2014, with all the tests in triplicate. The treatments were carried out at different pH levels (3.6, 7.0 and 10.4), and flotation/ozonation was catalyzed by manganese $\left(\mathrm{Mn}^{2+}\right)$ in neutral level (pH 7.0). Best removal efficiencies for chemical oxygen demand (COD) were obtained in acidic medium, with removals greater than $75 \%$ after 20 min of treatment. There was no significant difference with regards to addition of $\mathrm{Mn}^{2+}$ on COD removal by the physicochemical process. The kinetic models that best fit to the experimental data, for all treatments, were the asymptotic (residual) model and that of Chan and Chu. Treatment in acidic medium showed the highest values of the kinetic parameters for the adjusted model, obtaining a k coefficient equal to $0.2394 \mathrm{~min}^{-1}$ for the asymptotic model and kinetic coefficient $1 / \rho$ of $0.4816 \mathrm{~min}^{-1}$ for the Chan and Chu model, both presenting a determination coefficient greater than $99 \%$.
\end{abstract}

KEYWORDS: Asymptotic model. Chan and Chu model. AOP.

\section{INTRODUCTION}

Wastewater from the dairy industry contains high concentrations of nutrients and organic matter when compared to domestic wastewater (PRAZERES et al., 2012). To minimize the impacts of the treated dairy effluents not meeting the discharge standards on water bodies, new technologies are required. In recent decades, Advanced Oxidation Processes (AOPs) have been used as an alternative for the treatment of wastewaters from various processes (TRIPATHI et al., 2011; AVSAR et al., 2012; WU et al., 2012).

In the case of the dairy industry, there has been an intensified use of flotation in recent years, either by dispersed or dissolved air (CARVALHO et al., 2018). Flotation is a process of wide application in the treatment of oily wastewater, as an alternative preliminary treatment in the dairy industry for the removal of fat from industrial wastewater, which can harm the functioning of the treatment system (METCALF; EDDY, 2015).

There are already some published reports on flotation using ozone instead of atmospheric air to enhance the efficiency of the treatment systems (LEE et al., 2008; KIM et al., 2011).

Ozone can act as an AOP able to react with various organic compounds due to its high oxidation potential. AOPs are chemical treatment processes in which reactive species such as the hydroxyl radical $(\bullet \mathrm{OH})$ are generated and capable of oxidizing most organic compounds present in wastewater.

According to Gottschalk et al. (2000), for ozonation in acidic medium $(\mathrm{pH}<4)$, the direct reaction mechanism predominates, i.e., via molecular $\mathrm{O}_{3}$. As the $\mathrm{pH}$ increases, a larger quantity of ${ }^{\circ} \mathrm{OH}$ radicals are formed. For $\mathrm{pH}$ values exceeding 10, the decomposition of $\mathrm{O}_{3}$ into ${ }^{\circ} \mathrm{OH}$ radicals is instantaneous and the indirect reaction mechanism predominates (via ${ }^{\circ} \mathrm{OH}$ radicals). At $\mathrm{pH}$ levels around 7 the two reactions may occur, both direct and indirect, due to the presence of oxidizing agents.

Most of the compounds present in wastewaters react directly with ozone in reactions with extremely high rate constants, which indicates its use in reducing or eliminating these undesirable compounds (BELTRÁN, 2004). The understanding of the reactions rates occurring in wastewater treatment plants is important for design and operation of the reactors (SPERLING, 2014).

The formation or disappearance of compounds present in wastewater is described as the reaction rate $r$, and the relationship between the rate of reaction, reagent concentration and reaction order. According to Sperling (2014), in wastewater 
treatment systems the most frequent reactions are of order 0 and 1.

There are studies reporting that the first order kinetic model efficiently describes the removal of different compounds present in industrial wastewater by the ozonation process (GIRI et al., 2010; HASSANI et al., 2013). Chan and Chu (2003) proposed a non-linear pseudo first-order kinetic model to describe the degradation of pesticides in water by Fenton reagent. The regression results indicated that the degradation kinetics were well described by the proposed model.

Thus, the objective of this study was to fit first-order kinetic mathematical models and estimate their respective kinetic parameters to describe the degradation of organic matter in synthetic dairy wastewater by flotation/ozonation.

\section{MATERIAL AND METHODS}

The experiment was made during the year of 2014 using a synthetic wastewater to simulate the dairy industry wastewater, obtained by the addition of whole milk to distilled water to get a COD concentration of approximately $2,000 \mathrm{mg} \mathrm{L}^{-1}$ (BRIÃO; TAVARES, 2007).

After preparation of the synthetic solution the alkalinity of the sample was measured, finding an average value of $75.56 \mathrm{mg} \mathrm{L}^{-1} \mathrm{CaCO}_{3}$. This analysis is important to account for the presence of carbonates that may interfere with the treatment.

Ozone gas was obtained from an ozone generator Model O\&L 10.0 RM, developed by the company Ozone \& Life ${ }^{\circledR}$ (São Paulo, Brazil). The method used to quantify the ozone gas concentration was iodometry, by indirect titration (APHA, 2012).

Treatment by flotation/ozonation was performed in a washing flask (Pyrex) with $1 \mathrm{~L}$ capacity, where near its base was a porous diffuser (pores with 40 60 $\mu \mathrm{m}$ aperture) through which ozone gas with the concentration of $42 \mathrm{mg} \mathrm{L}^{-1}$ was introduced at a flow of $1.0 \mathrm{~L} \mathrm{~min}^{-1}$. Table 1 shows the conditions to which samples of the synthetic dairy wastewater were submitted for the tests.

Table 1. Conditions of the synthetic dairy wastewater used to obtain the degradation kinetics of organic material

\begin{tabular}{llll}
\hline Test & {$\left[\mathrm{O}_{3}\right]\left(\mathrm{mg} \mathrm{L}^{-1}\right)$} & {$\left[\mathrm{Mn}^{2+}\right]\left(\mathrm{mg} \mathrm{L}^{-1}\right)$} & $\mathrm{pH}$ \\
\hline 1 & 42.0 & - & 3.6 \\
2 & 42.0 & - & 7.0 \\
3 & 42.0 & - & 10.4 \\
4 & 42.0 & 0.04 & 7.0 \\
\hline
\end{tabular}

Batch tests were performed for an $\mathrm{O}_{3}$ exposure period of 240 min. During the reaction, samples were taken at times of $0,10,20,40,60,90$, 120, 180 and $240 \mathrm{~min}$. Each test was carried out in triplicates and the COD removal was analyzed using the colorimetric method (APHA, 2012).

To explain the degradation of organic material present in the synthetic dairy wastewater four first-order kinetic models or their modifications were tested as presented in Equations 1 to 4 . The equations represent the kinetic models of plug flow, continuous stirred tank reactor, residual model and Chan and Chu's model, respectively.

$$
\begin{aligned}
& \frac{C}{C_{n}}=e^{\left(-h t_{h}\right)} \\
& \frac{C}{C_{0}}=\frac{1}{1+h t_{h}} \\
& \frac{C}{C_{n}}=\left(1-C^{*}\right) e^{-k t_{h}}+C^{*} \\
& \frac{C}{C_{o}}=1-\frac{t_{h}}{\rho+\sigma t_{h}}
\end{aligned}
$$

For fitting of the kinetic models average experimental data was not used, but instead the data of the three samples were used. If the average was adopted there would be an increase in the $\mathrm{R}^{2}$ value. For measure the fittings, values of square root of the mean square error (RMSE), adjusted coefficient of determination $\left(\mathrm{R}_{\text {adjusted }}^{2}\right)$ and $\mathrm{R}^{2}$ were used.

The kinetic models studied were fitted to the observed data with the aid of the software Origin 9.1 (Origin Lab Corporation, Northampton, MA, USA). Determination of the kinetic coefficients was performed by nonlinear regression using the Levenbert Maquart algorithm.

\section{RESULTS AND DISCUSSION}

Figure 1 shows the average values with their respective standard deviations, for COD removal along the reaction period for the test conditions. 


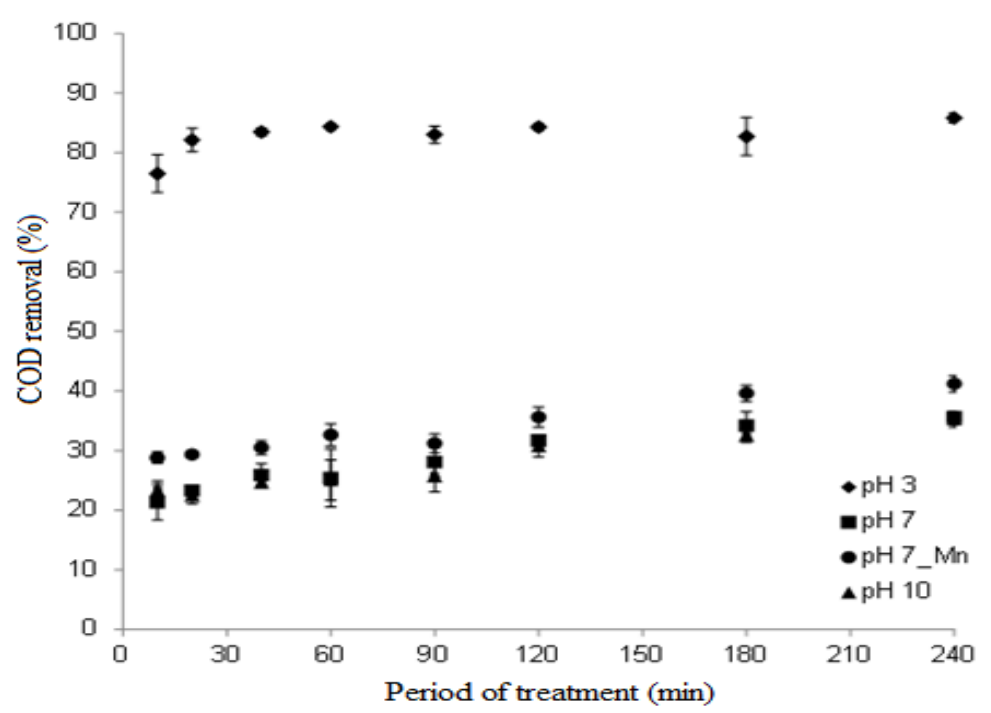

Figure 1. Effect of $\mathrm{pH}$ on COD removal from the synthetic dairy wastewater using flotation/ozonation process (42 $\mathrm{mg} \mathrm{L}^{-1}$ of ozone)

From Figure 1 it was observed that the acidic wastewater ( $\mathrm{pH}$ 3.6) showed better removal of COD with efficiency values greater than $75 \%$ in the first $10 \mathrm{~min}$ of treatment. On the other hand, removal efficiencies were very low for $\mathrm{pH} 7$ and 10.4. One explanation for this reduced efficiency of ozonation at $\mathrm{pH} 10.4$ and 7.0 compared with $\mathrm{pH} 3.6$ may be due to the presence of bicarbonates and carbonates in milk, and therefore in the wastewater $\left(\left[\mathrm{CaCO}_{3}\right]=75.56 \mathrm{mg} \mathrm{L}{ }^{-1}\right)$. The presence of "sequestrants" of hydroxyl radicals such as carbonates, bicarbonates and humic substances may reduce the efficiency of oxidation processes performed by this oxidizing agent $(\bullet \mathrm{OH})$, as in ozonation at high pH levels (LEGRINI et al., 1993; MASTEN; DAVIES, 1994).

Another explanation for the higher COD removal in acid medium is due to the natural coagulation/flocculation of milk proteins in the dairy effluents. According to Quick (1974), casein is the major protein found in milk (about 80\%) and has an average isoelectric point at $\mathrm{pH} 4.6$, therefore at this $\mathrm{pH}$ casein is found at its point of lowest solubility due to the decrease of intermolecular repulsions.

Without coagulation, both air bubbles and particles carry negative zeta potentials, negative charges. When particles approach, air bubbles the electrical double layers surrounding the particles and bubbles overlap causing a repulsive force, so that bubble collision and attachment is poor. For good coagulation, chemistry conditions and higher flotation efficiencies, it is expected that the flocs formed have little or no electrical charge, so electrostatic forces are low or near zero (EDZWALD, 2010).

Thus, part of the organic load may be removed by flotation (particles present in suspension adhere to ozone gas bubbles generated in the absorber bottle) and this aggregate (bubble particle) has a lower density than the suspension, thus it will rise in the aqueous solution and can be physically removed.

The wastewater under basic conditions $(\mathrm{pH}=10.4)$ submitted to ozonation showed better results than the neutral $(\mathrm{pH}=7)$ wastewater. However, during the $240 \mathrm{~min}$ of ozonation COD removal did not exceed $42 \%$. Addition of the catalyst $\left(\mathrm{Mn}^{2+}\right)$ showed no significant effect on the removal of COD from the wastewater.

Some authors (ASSALIN et al., 2006; MAHMOUD; FREIRE, 2007) observed improved removal efficiency of the organic load from wastewater when the catalyst $\mathrm{Mn}^{2+}$ was added to the ozonation process, at concentrations exceeding $1 \mathrm{mg}$ $\mathrm{L}^{-1}$. Therefore, the non-significance of $\mathrm{Mn}^{2+}$ addition may be explained by the low concentrations $\left(\left[\mathrm{Mn}^{2+}\right]<0.04 \mathrm{mg} \mathrm{L}{ }^{-1}\right)$ used in this study.

Fitting of the models based on first order kinetics to the experiment data was obtained using the software SigmaPlot 12.0 (Systat Software Inc., San Jose, CA, USA) and the coefficients for each model are presented in Table 2. 
Table 2. Fits of the $1^{\text {st }}$ order COD removal models to the results obtained for each test.

\begin{tabular}{|c|c|c|c|c|c|}
\hline Model & Parameter & pH 3.6 & $\mathrm{pH} 7$ & $\mathrm{pH} 7 / \mathrm{Mn}^{2+}$ & $\mathrm{pH} 10.4$ \\
\hline \multirow{4}{*}{1} & $\mathrm{k}\left(\min ^{-1}\right)$ & 0.1267 & 0.0028 & 0.0027 & 0.0035 \\
\hline & $\mathrm{R}^{2}$ & 0.7162 & 0.3794 & 0.4952 & 0.6839 \\
\hline & $\mathrm{R}_{\text {adjusted }}^{2}$ & 0.7162 & -0.3794 & -0.4952 & -0.6839 \\
\hline & RMSE & 0.5382 & 0.3828 & 0.3791 & 0.5904 \\
\hline \multirow{4}{*}{2} & $\mathrm{k}\left(\min ^{-1}\right)$ & 0.2162 & 0.0038 & 0.0036 & 0.0051 \\
\hline & $\mathrm{R}^{2}$ & 0.8616 & 0.0901 & 0.2156 & 0.3004 \\
\hline & $\mathrm{R}_{\text {adjusted }}^{2}$ & 0.8616 & -0.0901 & -0.2156 & -0.3004 \\
\hline & RMSE & 0.2624 & 0.3025 & 0.3082 & 0.4559 \\
\hline \multirow{5}{*}{3} & $\mathrm{k}\left(\min ^{-1}\right)$ & 0.2394 & 0.0933 & 0.1272 & 0.1487 \\
\hline & $\mathrm{C}^{*}$ & 0.1639 & 0.6975 & 0.7130 & 0.6521 \\
\hline & $\mathrm{R}^{2}$ & 0.9939 & 0.8553 & 0.8256 & 0.8916 \\
\hline & $\mathrm{R}_{\text {adjusted }}^{2}$ & 0.9938 & 0.8495 & 0.8256 & 0.8873 \\
\hline & RMSE & 0.0114 & 0.0401 & 0.0425 & 0.0380 \\
\hline \multirow{5}{*}{4} & $1 / \rho$ & 0.4816 & 0.0413 & 0.0529 & 0.0859 \\
\hline & $1 / \sigma$ & 0.8625 & 0.3325 & 0.3121 & 0.3714 \\
\hline & $\mathrm{R}^{2}$ & 0.9893 & 0.9282 & 0.8819 & 0.9094 \\
\hline & $\mathrm{R}_{\text {adjusted }}^{2}$ & 0.9889 & 0.9254 & 0.8819 & 0.9058 \\
\hline & RMSE & 0.0202 & 0.0251 & 0.0288 & 0.0251 \\
\hline
\end{tabular}

First order kinetic models: (1) Plug flow PFR; (2) Continuous stirred tank CSTR; (3) Asymptotic or Residual; (4) Chan and Chu.

It can be observed (Table 2), that for all treatments the highest $R^{2}$ and $R_{\text {adjusted }}^{2}$ values found were obtained for the models Asymptotic and Chan and Chu. These models also had the lowest estimated error values (RMSE).

Salgado et al. (2009) also used the kinetic model of Chan and Chu to obtain the efficiency of the photolytic AOP for removal of color in synthetic wastewater containing Indigo Carmine. For the model parameters, these authors found values for $\rho^{-1}$ and $\sigma^{-1}$ of 0.65 and 1.06 , respectively, very close to those found in the present study when using $\mathrm{pH}$ 3.6.

In Chan and Chu model, the inverse of the constant $\rho$ corresponds to an initial COD degradation rate, consequently the higher the $\rho^{-1}$ faster is the removal of COD from the wastewater. Moreover, the inverse of $\sigma$ corresponds to the maximum possible conversion or maximum degradation of COD.

Figures 2 and 3 shows the regression curves for the dairy wastewater at $\mathrm{pH}(\mathrm{s}) 3.6,7,10.4$ and $\mathrm{pH}$ 7 with and without the presence of $\mathrm{Mn}^{2+}$ using the asymptotic (or residual) model and the Chan and Chu model respectively.

From Figures 2 and 3 it can be seen that the results of COD removal at the $\mathrm{pH}(\mathrm{s}) 10.4,7$ and 7 with the manganese catalyst were very similar. There was no significant difference $(95 \%$ confidence interval) between the regression models of $\mathrm{pH} \quad 7$ and 7/Mn (CARVALHO; CHRISTOFFOLETI, 2007). Therefore, this further confirms that the addition of $0.04 \mathrm{mg} \mathrm{L}^{-1}$ of the catalyst did not enhance the flotation/ozonation efficiency

According to Figures 2 and 3, from a kinetic point of view it can be observed that the experiment in acidic medium ( $\mathrm{pH}$ 3.6) was most efficient, presenting the most promising kinetic constants, $\mathrm{k}$ equal to $0.2394 \mathrm{~min}^{-1}$ for the asymptotic or residual model and $\rho$ equal to $0.4816 \mathrm{~min}^{-1}$ for the model of Chan and Chu .

Santos et al. (2011), while treating wastewater containing the azodye Red GRLX-220 to ozonation, also found that the kinetic constant of the pseudo-first order model was higher in acidic medium $\left(\mathrm{k}=0.174 \mathrm{~min}^{-1}\right)$ compared to the basic medium $\left(\mathrm{k}=0.154 \mathrm{~min}^{-1}\right)$. However, Mahmoud and Freire (2007) studied the kinetic behavior of ozonation for the degradation of the azodye Remazol Black B, and found that the kinetic constant in basic medium was higher $(\mathrm{k}=0.035$ $\mathrm{min}^{-1}$ ) when compared with the kinetic constant obtained in acid medium $\left(0.0067 \mathrm{~min}^{-1}\right)$.

Kern et al. (2012) studied conventional ozonation of wastewater from a hospital laundry. The authors found that in acid medium ( $\mathrm{pH} 3$ to 3.5 ) the kinetic constant of COD degradation was 0.0036 $\mathrm{min}^{-1}$, with a coefficient of determination equal to $97 \%$.

Analysis of the confidence intervals (95\%) shows a significant difference for ozonation in neutral and basic media, where treatment at $\mathrm{pH} 10.4$ gave better results with respect to the neutral medium. 


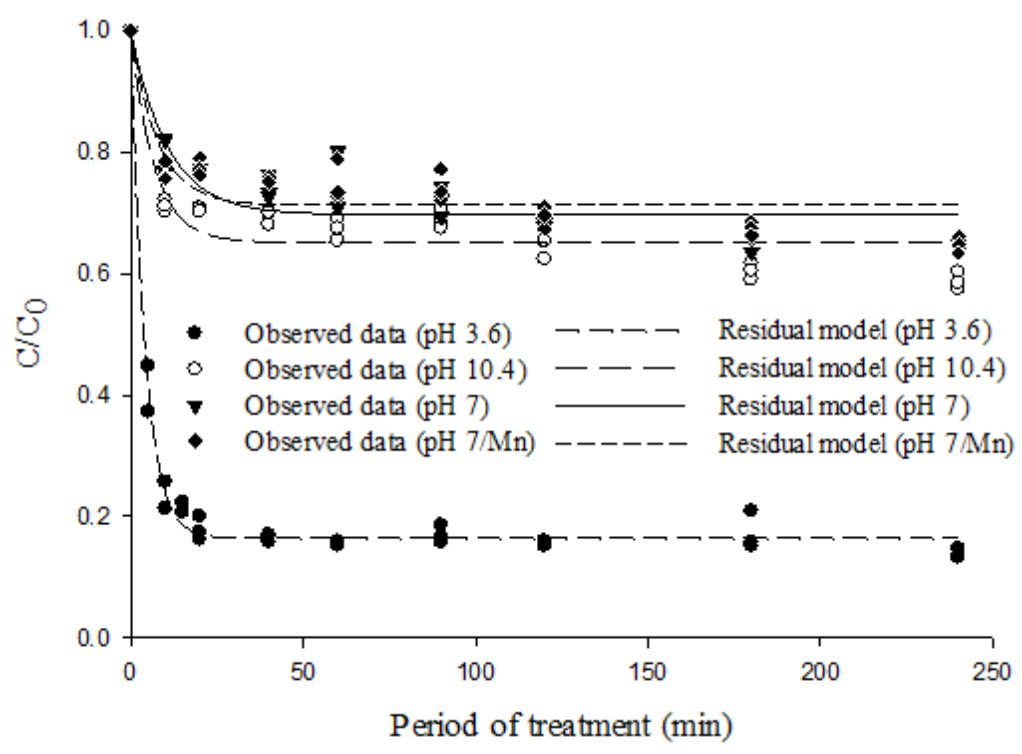

Figure 2. Asymptotic or residual model fitted to the observed data for flotation/ozonation at $\mathrm{pH} 3.6,7,10.4$, and 7 with or without presence of the $\mathrm{Mn}^{2+}$ catalyst

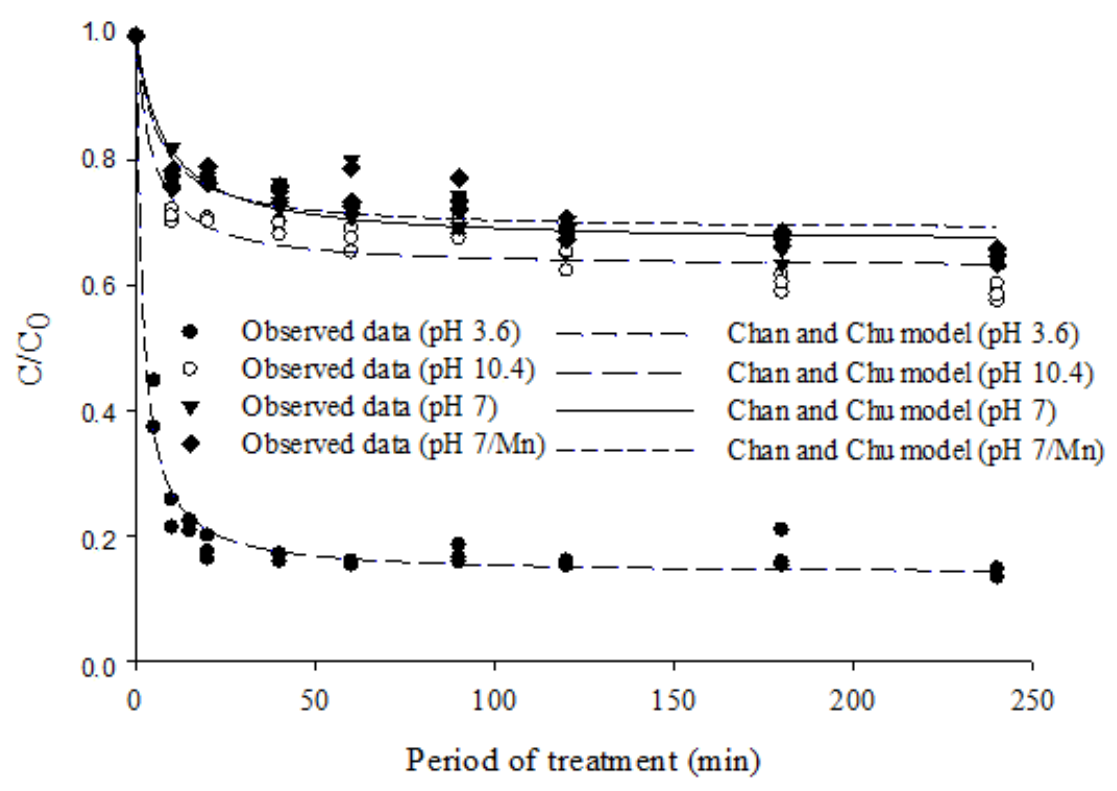

Figure 3. Chan and Chu model fitted to the observed data for flotation/ozonation at $\mathrm{pH} 3.6,7,10.4$, and 7 with or without presence of the $\mathrm{Mn}^{2+}$ catalyst

Table 3 shows the equations obtained for the asymptotic and Chan and Chu kinetic models, as well as the respective required periods of flotation/ozonation calculated to remove $75 \%$ of COD from the synthetic dairy wastewater. The value of $75 \%$ was adopted based on the DN COPAM/CERH-MG 1/2008, which established that the minimum limit for wastewater discharging into a receiving water body, with respect to COD is 180 $\mathrm{mg} \mathrm{L}^{-1}$, i.e., the treatment must be $75 \%$ efficient, with no alteration to the original conditions of the water body.
The asymptotic or residual model considers that a recalcitrant fraction $\left(\mathrm{C}_{\mathrm{r}}\right)$ of the organic compound is not degraded. Therefore, based on the obtained coefficients $\left(\mathrm{C}^{*}\right)$, for the acidic medium the remaining COD concentration would be $328.0 \mathrm{mg}$ $\mathrm{L}^{-1}$, while for the neutral $\mathrm{pH}$ this concentration could be $1427.0 \mathrm{mg} \mathrm{L}^{-1}$. 
Table 3. Adjusted kinetic equations, their respective coefficients and the period of treatment necessary to remove $75 \%$ of the COD

$\begin{array}{lll}\text { Model } & \text { Equation } & \mathrm{t}_{75 \%}(\min )\end{array}$

Residual $\quad \frac{C}{C_{0}}=(1-0.1639) e^{-0.2394 t_{h}}+0.1639$

Chan and Chu $\quad \frac{\mathrm{C}}{\mathrm{C}_{0}}=1-\frac{\mathrm{t}_{\mathrm{h}}}{2.0764+1.1594 \mathrm{t}_{\mathrm{h}}}$

Because the asymptotic and Chan and Chu models showed good fit to the COD degradation kinetics, considering the synthetic dairy wastewater ozonized in acidic medium ( $\mathrm{pH}$ 3.6) at an ozone concentration of $42 \mathrm{mg} \mathrm{L}^{-1}$, the treatment period required to satisfy legislation may vary between 9.51 and $11.94 \mathrm{~min}$ for the wastewater to reach discharge standards, with respect to COD.

\section{CONCLUSIONS}

The degradation of organic matter in synthetic dairy wastewater by flotation/ozonation was investigated. For all treatments the kinetic models that best fitted to the experimental data were the asymptotic or residual model and the model of Chan and Chu.
Ozonation in acidic medium ( $\mathrm{pH}$ 3.6) was the treatment that presented the highest kinetic constants for the adjusted models. For the asymptotic model a kinetic constant $(\mathrm{k})$ of 0.2394 $\mathrm{min}^{-1}$ was obtained, and for the model of Chan and Chu the kinetic constant $(1 / \rho)$ was found to be $0.4816 \mathrm{~min}^{-1}$. For both models the coefficient of determination $\left(\mathrm{R}^{2}\right)$ was greater than 0.99 .

\section{ACKNOWLEDGEMENTS}

We thank the "Conselho Nacional de Desenvolvimento Científico e Tecnológico" for the scholarship to M. C. S. Carvalho. The authors also thank Mr Evan M. Visser for the translation of this paper.

RESUMO: Neste estudo, avaliou-se o ajuste de quatro modelos cinéticos (modelo de escoamento pistonado, mistura completa, assintótico ou residual e de Chan e Chu e seus respectivos parâmetros, na degradação da matéria orgânica presente no efluente de laticínios pelo processo físico-químico de flotação e ozonização. O experimento foi implementado durante o ano de 2014, com todos os testes em triplicata, os s tratamentos foram realizados sob diferentes pHs $\left(3,6 ; 7,0\right.$ e 10,4), além da flotação/ozonização catalisada pelo manganês $\left(\mathrm{Mn}^{2+}\right)$ em meio neutro. Observando que em meio ácido ocorreram as melhores eficiências de remoção da demanda química de oxigênio (DQO), tendo sido obtida uma remoção superior a $75 \%$ em 20 min de tratamento. Não houve diferença significativa em relação à adição de $\mathrm{Mn}^{2+}$ ao processo físico-químico. Os modelos que mais se ajustaram aos dados experimentais, para todos os tratamentos realizados, foram o modelo assintótico e o de Chan e Chu. O tratamento em meio ácido foi o que apresentou os maiores valores dos parâmetros cinéticos para os modelos ajustados, obtendo-se para o modelo assintótico, coeficiente k igual a 0,2394 min ${ }^{-1}$, e para o modelo de Chan e Chu, coeficiente cinético $1 / \rho$ de $0,4816 \mathrm{~min}^{-1}$, apresentando para ambos os modelos um coeficiente de determinação superior a $99 \%$.

PALAVRAS-CHAVE: Modelo assintótico. Modelo de Chan e Chu. POA

\section{REFERENCES}

APHA - AMERICAN PUBLIC HEALTH ASSOCIATION. Standard methods for the examination of water and wastewater. 22.ed. Washington: American Public Health Association, American Water Works Association, Water Environment Federation, 2012. 1496 p. 
ASSALIN, M. R.; SILVA, P. L.; DURAN, N. Comparação da eficiência do processo de ozonização e ozonização catalítica (Mn II e Cu II) na degradação de fenol. Química Nova, v. 29, n. 1, p. 24-27, 2006. https://doi.org/10.1590/S0100-40422006000100006

AVSAR, Y.; KABUK, A. H.; KURT, U.; CAKMAKCI, M.; OZKAYA, B. Biological treatability processes of textile wastewaters using electrocoagulation and ozonation. Journal of Scientific \& Industrial Research, v. 71, n. 7, p. 496-500, 2012.

BELTRÁN, F. J. Ozone reaction kinetics for water and wastewater systems. Boca Raton: Lewis Publishers, 2004. $384 \mathrm{p}$.

BRIÃO, V. B.; TAVARES, C. R. G. Effluent generation by the dairy industry: preventive attitudes and opportunities. Brazilian Journal of Chemical Engineering, v. 24, n. 4, p. 487-497, 2007.

https://doi.org/10.1590/S0104-66322007000400003

CARVALHO, M. C. S.; BORGES, A. C.; PEREIRA, M. S.; HELENO, F. F.; FARONI, L. R. A.; CAMPOS, L. C. Uso combinado de $\mathrm{O}_{3} / \mathrm{H}_{2} \mathrm{O}_{2}$ e $\mathrm{O}_{3} / \mathrm{Mn}^{2+}$ para flotação de águas residuárias de laticínio. Revista Ambiente e Água, v. 13, n.2, p. 1-15, 2018. http://dx.doi.org/10.4136/ambi-agua.2078

CARVALHO, S. J. P.; CHRISTOFFOLETI, P. J. Estimativa da área foliar de cinco espécies do gênero Amaranthus usando dimensões lineares do limbo foliar. Planta Daninha, v. 25, n. 2, p. 17-324, 2007. https://doi.org/10.1590/S0100-83582007000200011

CHAN, K. H.; CHU, W. Modeling the reaction kinetics of fenton's process on the removal of atrazine. Chemosphere, v. 51, n. 4, p. 305-311, 2003. https://doi.org/10.1016/S0045-6535(02)00812-3

EDZWALD, J. K. Dissolved air flotation and me. Water Research, v. 44, n. 7, p. 2077-2100, 2010. https://doi.org/10.1016/j.watres.2009.12.040

GIRI, R. R.; OZAKI, H.; OTA, S.; TAKANAMI, R.; TANIGUCHI, S. Degradation of common pharmaceuticals and personal care products in mixed solutions by advanced oxidation techniques. International Journal of Environment Science and Technology, v. 7, n. 2, p. 251-260, 2010. https://doi.org/10.1007/BF03326135

GOTTSCHALK, C.; LIBRA, A. J.; SAUPE, A. Ozonation of water and wastewater: a practical guide to understanding ozone and its applications. Weinheim: Wiley-VCH, 2000. 189 p.

https://doi.org/10.1002/9783527613342

HASSANI, A. H.; BORGHEI, S. M.; SAMADYAR, H.; MIRBAGHERI, S. A.; JAVID, A. H. Treatment of wastewater containing ethylene glycol using ozonation: Kinetic and performance study. Bulletin of Environment, Pharmacology and Life Sciences, v. 2, n. 9, p. 78-82, 2013.

KERN, D. I.; SCHWAICKHARDT, R. O.; MOHR, G.; LOBO, E. A.; KIST, L. T.; MACHADO, E. L. Toxicity and genotoxicity of hospital laundry wastewaters treated with photocatalytic ozonation. Science of the Total Environment, v. 443, p. 566-572, 2012. https://doi.org/10.1016/j.scitotenv.2012.11.023

KIM, J. H.; KIM, H. S.; LEE, B. H. Combination of sequential bath reactor (SBR) and dissolved ozone flotation-pressurized ozone oxidation $\left(\mathrm{DOF}-\mathrm{PO}_{2}\right)$ processes for treatment of pigment processing wastewater. Environmental Engineering Research, v. 16, n. 2, p. 97-102, 2011. https://doi.org/10.4491/eer.2011.16.2.97

METCALF \& EDDY. Inc. Wastewater Engineering: Treatment and Resource Recovery. 5. ed. New York: McGraw-Hill Book, 2013. 2048 p. 
LEE, B. H.; SONG, W. C.; MANNA, B.; HA, J. K. Dissolved ozone flotation (DOF) - a promising technology in municipal wastewater treatment. Desalination, v. 225,n. 1-3, p. 260-273, 2008.

https://doi.org/10.1016/j.desal.2007.07.011

LEGRINI, O.; OLIVEROS, E.; BRAUN, A. M. Photochemical processes for water treatment. Chemical Review, v. 93, n.2, p. 671-698, 1993. https://doi.org/10.1021/cr00018a003

MAHMOUD, A.; FREIRE, R. S. Métodos emergentes para aumentar a eficiência do ozônio no tratamento de águas contaminadas. Química Nova, v. 30, n.1, p. 198-205, 2007. https://doi.org/10.1590/S0100-

40422007000100032

MASTEN, S. J.; DAVIES, S. H. R. The use of ozonation to degrade organic contaminants in wastewaters. Environment Science and Technology, v. 28, n.4, p. 180-185, 1994. https://doi.org/10.1021/es00053a001 https://doi.org/10.1021/es00053a718

PRAZERES, A.R.; CARVALHO, F; RIVAS, J. Cheese whey management: A review. Science of the Total Environment, v. 445-446, p. 385-396, 2012. https://doi.org/10.1016/j.jenvman.2012.05.018

QUIRK, T. P.; ZAMBRANO, J. J. ; HELLMAN, J. Whey effluent packed tower trickling filtration. United States. Environmental Protection Agency. Office of Research and Monitoring Environmental Protection Agency, U.S. Govt. Print. Off., 1972. 179 p.

SALGADO, B. C. B.; NOGUEIRA, M. I. C.; RODRIGUES, K. A.; SAMPAIO, G. M. M.; BUARQUE, H. L. B.; ARAUJO, R. S. Descoloração de efluentes aquosos sintéticos e têxtil contendo corantes índigo e azo via processos Fenton e foto-assistidos (UV e UV/ $\mathrm{H}_{2} \mathrm{O}_{2}$ ). Engenharia Sanitária e Ambiental, v. 14, n.1, p. 1-8, 2009. https://doi.org/10.1590/S1413-41522009000100001

SANTOS, P. K.; FERNANDES, K. C.; FARIA, L. A.; FREITAS, A. C. SILVA, L. M. Descoloração e degradação do azo corante vermelho GRLX-220 por ozonização. Química Nova, v. 34, n.8, p. 1315-1322, 2011. https://doi.org/10.1590/S0100-40422011000800004

SPERLING, M. Introdução à qualidade das águas e ao tratamento de esgotos. Belo Horizonte: Departamento de Engenharia Sanitária e Ambiental, 2014. 452 p.

TRIPATHI, S., PATHAK, V., TRIPATHI, D. M.; TRIPATHI, B. D. Application of ozone based treatments of secondary effluents. Bioresourse Technology, v. 102, n.3, p. 2481-2486, 2011.

https://doi.org/10.1016/j.biortech.2010.11.028

WU, D., YANG, Z., WANG, W., TIAN, G., XU, S.; SIMS, A. Ozonation as an advanced oxidant in treatment of bamboo industry wastewater. Chemosphere, v. 88, n.9, p. 1108-1113, 2012.

https://doi.org/10.1016/j.chemosphere.2012.05.011 